Article

\title{
Light Regulation of Two New Manganese Peroxidase-Encoding Genes in Trametes polyzona KU-RNW027
}

\author{
Piyangkun Lueangjaroenkit ${ }^{1}$, Emi Kunitake ${ }^{2}$, Makiko Sakka ${ }^{2}$, Tetsuya Kimura ${ }^{2}$, \\ Churapa Teerapatsakul ${ }^{1}$, Kazuo Sakka ${ }^{2}$ and Lerluck Chitradon ${ }^{1, *(D)}$ \\ 1 Department of Microbiology, Faculty of Science, Kasetsart University, Bangkok 10900, Thailand; \\ fscipkl@ku.ac.th (P.L.); fscicpt@ku.ac.th (C.T.) \\ 2 Laboratory of Applied Microbiology, Graduate School of Bioresources, Mie University, 1577 \\ Kurimamachiya-cho, Tsu, Mie 514-8507, Japan; Kunitake@bio.mie-u.ac.jp (E.K.); \\ makiko@bio.mie-u.ac.jp (M.S.); t-kimura@bio.mie-u.ac.jp (T.K.); sakka@bio.mie-u.ac.jp (K.S.) \\ * Correspondence: fscillc@ku.ac.th; Tel.: +66-(0)2-562-5555 (ext. 646624)
}

Received: 7 April 2020; Accepted: 27 May 2020; Published: 5 June 2020

check for updates

\begin{abstract}
To better understand the light regulation of ligninolytic systems in Trametes polyzona KU-RNW027, ligninolytic enzymes-encoding genes were identified and analyzed to determine their transcriptional regulatory elements. Elements of light regulation were investigated in submerged culture. Three ligninolytic enzyme-encoding genes, mnp1, mnp2, and lac1, were found. Cloning of the genes encoding MnP1 and MnP2 revealed distinct deduced amino acid sequences with 90\% and 86\% similarity to MnPs in Lenzites gibbosa, respectively. These were classified as new members of short-type hybrid MnPs in subfamily A.2 class II fungal secretion heme peroxidase. A light responsive element (LRE), composed of a 5'-CCRCCC-3' motif in both mnp promoters, is reported. Light enhanced MnP activity 1.5 times but not laccase activity. The mnp gene expressions under light condition increased 6.5- and 3.8-fold, respectively. Regulation of laccase gene expression by light was inconsistent with the absence of LREs in their promoter. Blue light did not affect gene expressions but impacted their stability. Reductions of $\mathrm{MnP}$ and laccase production under blue light were observed. The details of the molecular mechanisms underlying enzyme production in this white-rot fungus provide useful knowledge for wood degradation relative to illumination condition. These novel observations demonstrate the potential of enhancing ligninolytic enzyme production by this fungus for applications with an eco-friendly approach to bioremediation.
\end{abstract}

Keywords: light; manganese peroxidase; Trametes polyzona; gene expression; enzyme production; light responsive element

\section{Introduction}

Light is an important environmental factor for phototrophic organisms, such as plants, algae, and phototrophic microorganisms, and for non-phototrophic microorganisms, including fungi [1]. Fungi use photoreceptors as eye-like sensors to detect light of specific wavelengths, such as phytochrome for red light, opsin for green light, white collar and vivid flavoprotein for blue light, and cryptochrome for white light [2-5]. Therefore, light-driven regulation corresponds to specific types of photoreceptors. Fundamental light-driven processes in fungi include cell development [6], protein secretion [7], conidiation [8], fungal spore germination [9], fruiting body formation [10], virulence of pathogenic fungi [11], carotenoid synthesis [12], and pigmentation [13].

The effect of light on the production of ligninolytic enzymes such as lignin peroxidase (LiP) and laccase has been investigated previously [14,15]. Green light enhanced lignin peroxidase production in Phanerochaete chrysosporium under submerged culture, whereas red, blue, and UV light reduced 
productivity [14]. Blue light efficiently boosted laccase production in Cerrena unicolor and Pycnoporus sanguineus, whereas white light increased laccase production in Phlebia lindtneri [15]. These results indicated that light diversely affects each fungus. Light-dependent control of transcription using an artificial on-off switchable promoter in Trichoderma reesei was reported [16].

The cis-acting regulatory sequence elements are contained in promotor regions that are selectively recognized by trans-acting transcription factors to regulate gene expression [17]. Several functional cis-acting regulatory sequence elements have been identified in promoter regions to achieve activation or deactivation of mRNA translation. Metal responsive element (MRE) and xenobiotic responsive element (XRE) are commonly-found cis-acting regulatory sequence elements which are involved in non-specific metal-ion and aromatic-compound-regulated gene expression of ligninolytic enzymes [17-19]. Light responsive elements (LREs) have been identified in plant promoters for light-regulated gene expression systems [20]. However, no reports have been published concerning the effects of LREs on promoters of ligninolytic enzyme-encoding genes.

Trametes polyzona KU-RNW027 is a white rot fungus that exhibits high manganese peroxidase (MnP) and laccase activities with efficacy on dyes and pharmaceutical product degradation [21,22]. Here, the aim was to investigate the enzyme-encoding genes in the ligninolytic system of Trametes polyzona KU-RNW027 and how they regulate enzyme production and enzyme-gene expression under conditions of illumination. Genes encoding two MnPs and one laccase were cloned and identified. Phylogenetic relationships of MnPs and laccase were analyzed by their amino acid sequence similarities. The promoter sequences of $m n p 1, m n p 2$, and lac1 genes were analyzed for cis-acting regulatory sequence elements. The light-driven regulation of ligninolytic enzyme production and its gene expressions in a submerged culture of T. polyzona KU-RNW027 were also investigated.

\section{Materials and Methods}

\subsection{Microorganism and Inoculum Preparation}

The white rot fungus, T. polyzona KU-RNW027, was maintained on potato dextrose agar (PDA) and stored in $20 \%$ glycerol at $-20^{\circ} \mathrm{C}$ for long-term preservation. For inoculum preparation, this fungus was cultured in $50 \mathrm{~mL}$ Kirk's liquid medium for 3 days to prepare fungal pellet inoculum following Lueangjaroenkit et al. [21]. Fungal pellets $(0.05 \mathrm{~g} / \mathrm{L})$ were used as inoculum in all experiments.

\subsection{Plate Assay of Light-Driven Ligninolytic Enzyme Activity}

A plug of mycelial tip with a $0.5 \mathrm{~cm}$ diameter was inoculated on PDA plates supplemented with $1 \mathrm{mM}$ 2,6-dimethoxy phenol (2,6-DMP). The fungus was cultured under continuous lighting with a tungsten incandescent bulb. Light intensity was set to 500 lux. For the dark control, plates were fully covered with aluminum foil. PDA without 2,6-DMP was used as the control. All cultures were incubated at $30^{\circ} \mathrm{C}$ for 3 days. Ligninolytic enzymes oxidized 2,6-DMP to an orange product, allowing the visualization of enzyme activity.

\subsection{Effect of Light on Transcription Levels and Enzyme Production}

T. polyzona KU-RNW027 was grown in $50 \mathrm{~mL}$ of Kirk's liquid medium and exposed to light sources for 7 days. Tungsten incandescent bulb and blue light emitting diode (LED) were used. Tungsten incandescent bulbs had a broad spectrum of 320-1100 nm. The wavelength of the blue LED was $465 \mathrm{~nm}$ and the light intensity was set to 500 lux. The cultures were incubated under shaking at $130 \mathrm{rpm}, 30^{\circ} \mathrm{C}$. The control was incubated in the dark and flasks were fully covered with aluminum foil to prevent light penetration. Ligninolytic enzyme activities, gene expression at the transcription level, and fungal growth were determined. All experiments were performed in triplicate.

\subsection{Enzyme Stability under Different Wavelengths of Light}

Enzyme stability toward different light wavelengths was evaluated at $30^{\circ} \mathrm{C}$ by pre-incubating the ligninolytic enzyme under continuous lighting with a tungsten incandescent bulb for visible light and 
blue LED light for $72 \mathrm{~h}$. Light intensity was set to 500 lux. Residual activities were determined at 1, 3, $6,24,48$, and $72 \mathrm{~h}$. All experiments were performed in triplicate.

\subsection{Enzyme Assay}

$\mathrm{MnP}$ and laccase activity assays were performed according to the method of Lueangjaroenkit et al. [21] and Kondo et al. [23]. MnP and laccase activities were determined by monitoring the oxidation of 2,6-DMP at $469 \mathrm{~nm}$, and its absorbency change followed within $3 \mathrm{~min}$. For laccase assay, the reaction mixture consisted of $1 \mathrm{mM}$ 2,6-DMP in $50 \mathrm{mM}$ malonate buffer ( $\mathrm{pH}$ 4.5). For the MnP assay, the reaction mixture consisted of $1 \mathrm{mM} \mathrm{2,6-DMP,} 1 \mathrm{mM} \mathrm{MnSO}_{4}$, and $0.1 \mathrm{mM} \mathrm{H}_{2} \mathrm{O}_{2}$ in malonate buffer ( $\mathrm{pH} 4.5)$. The result for the latter procedure is expressed as total activity (laccase $+\mathrm{MnP}$ activity). Differences between activities of laccase and total activity were used to calculate MnP activity. Enzyme denaturation at $100^{\circ} \mathrm{C}$ for $15 \mathrm{~min}$ was performed as a control reaction in parallel. One unit (U) of either $\mathrm{MnP}$ or laccase was defined as activity oxidizing $1 \mu \mathrm{mol}$ of substrate per min.

\subsection{Cloning of Ligninolytic Enzyme-Encoding Genes and Promoter Region}

Genomic DNA was extracted from the mycelia cultivated in Kirk's liquid medium as previously described [21]. In brief, mycelia were ground in liquid nitrogen and lysis extraction buffer was then added. After incubation on ice for $30 \mathrm{~min}, 50 \mu \mathrm{L}$ of $5 \mathrm{M}$ potassium acetate $(\mathrm{pH} 4.8)$ was added and the mixture was further incubated on ice for $15 \mathrm{~min}$ before centrifuging. The supernatant was transferred into a new tube. DNA precipitation was conducted using isopropanol. Genomic DNA was washed with $70 \%$ ethanol. Finally, DNA pellets were resuspended in ultrapure water.

Degenerate primers for mnp were designed according to LC-MS/MS based protein fingerprints of MnPs [22], whereas degenerate primers for lac were designed based on the conserved nucleotide sequence of lac from related species in genus Trametes and are listed in Table S1. The fragments were amplified by PCR with LA Taq DNA polymerase (Takara Bio, Kusatsu, Japan). To obtain the $5^{\prime}$ and $3^{\prime}$ flanking of the ligninolytic enzyme-encoding genes mnp1, mnp2, and lac1, inverse PCR was performed with the primers listed in Table S1. Genomic DNA of T. polyzona KU-RNW027 was digested with restriction enzymes BglII, StyI, and BamHI, and self-ligated using DNA ligation kit version 2.1 (Takara Bio, Kusatsu, Japan). Inverse PCR was performed with LA Taq DNA polymerase (Takara Bio, Kusatsu, Japan) using self-ligated DNA as the template and inverse PCR primer pairs (Table S1). The inverse primers were designed based on known sequences of mnp1, mnp2, and lac1. All PCR products were purified and cloned into pUC19 vector. Escherichia coli DH5 $\alpha$ was transformed with pUC19 recombinants and cultured on Luria-Bertani medium supplemented with $50 \mu \mathrm{g} / \mathrm{mL}$ ampicillin at $37^{\circ} \mathrm{C}$ for $16-18 \mathrm{~h}$. Recombinant plasmids were extracted using Qiagen Plasmid Purification Kit (Qiagen Inc., Germantown, MD, USA). The sequencing reaction was performed using Dye Terminator Cycle Sequencing Kit (Beckman Coulter Inc., Indianapolis, IN, USA) and M13f and M13r universal primers. Sequences were analyzed on a Beckman Coulter CEQ 2000 DNA sequencer (Beckman Coulter Inc., Indianapolis, IN, USA).

\subsection{Cloning of cDNA of mnp1, mnp2, and lac1}

Total RNA was extracted using TRIzol Reagent ${ }^{\circledR}$ (Molecular Research Center Inc., Cincinnati, OH, USA). Total cDNA was synthesized from the total RNA using ReverTra Ace ${ }^{\circledR}$ qPCR RT Master Mix with gDNA Remover (Toyobo, Osaka, Japan). Using the total cDNA as a template with degenerate primer pairs (MnPf and MnPr for mnp and Lacf and Lacr for lac), $0.8 \mathrm{~kb} m n p$ and $1 \mathrm{~kb}$ lac fragments were amplified by PCR with LA Taq DNA polymerase (Takara Bio, Kusatsu, Japan). Based on the nucleotide sequences of these fragments, specific primers for $5^{\prime}$ and $3^{\prime}$ rapid amplification of cDNA ends ( $5^{\prime} / 3^{\prime}$-RACE Kit, Roche Diagnostics, Mannheim, Germany) were designed to perform cloning of the full-length of cDNA, as shown in Table S1. All PCR products were purified and cloned into pT7blue vector (Novagen, Madison, WI, USA). Sequences were analyzed. The cDNA sequences of ligninolytic enzyme-encoding genes were aligned with those of other fungi by Blast analysis in 
GenBank database (http://www.ncbi.nlm.nih.gov/). A phylogenetic tree of the deduced amino acid sequences was constructed using the Mega6 program using the maximum likelihood method with 1000 bootstrap resampling replicates [24]. A putative signal peptide was analyzed using SignalP 4.0 [25].

\subsection{Analysis of Gene Expression by Quantitative Real-Time PCR (qRT-PCR)}

Total cDNA was synthesized as mentioned in Section 2.7. The template cDNA was diluted five times with $10 \mathrm{mM}$ Tris- $\mathrm{HCl}(\mathrm{pH}$ 8.0). RNA was quantified by measuring its absorbency at A260 using NanoDrop One (Thermo Fisher Inc., Waltham, MA, USA). RNA purity and quality were checked by A260/280 and A260/A230 ratios and gel electrophoresis, respectively. mnp1, mnp2, and lac1 expressions were quantified using StepOnePlus Real-Time PCR system (Thermo Fisher Scientific Inc., Waltham, MA, USA). qRT-PCR was performed using the primer sets listed in Table S2. Reactions were conducted using Thunderbird SYBR qPCR Mix (Toyobo, Osaka, Japan) following the manufacturer's instructions. Briefly, qRT-PCR was performed with pre-denaturation at $95^{\circ} \mathrm{C}$ for $60 \mathrm{sec}$ followed by 40 cycles of denaturation at $95^{\circ} \mathrm{C}$ for $15 \mathrm{~s}$ and annealing and extension at $60^{\circ} \mathrm{C}$ for $30 \mathrm{~s}$. In the final step, the melting curve was analyzed.

Standard curves of mnp1, mnp2, and lac1 amplification were generated using PCR products amplified from total cDNA of T. polyzona KU-RNW027. Transcription levels are expressed as induction fold. This is a copy number of target genes, mnp1, mnp2, or lac1, referred to as the copy number of the housekeeping gene. In this study, the rRNA gene was used as the housekeeping gene. All experiments were performed in triplicate.

\subsection{Statistical Analysis}

All experiments were conducted in triplicate. A pairwise multiple comparison procedure following Student-Newman-Keuls post-hoc tests was used to identify sample means that were significantly different from each other. SigmaPlot 11 (Systat Software Inc., San Jose, CA, USA) was used to calculate statistical probabilities. A $p$-value $<0.05$ indicated statistically significant differences between means of maximum enzyme activities, transcription level, and fungal growth at a $95 \%$ confidence interval.

\section{Results and Discussion}

\subsection{Ligninolytic Enzyme-Encoding Genes of T. polyzona KU-RNW027}

Using MnPf and MnPr as the degenerate primers, 1014 and $1016 \mathrm{bp}$ fragments of mnp1 and mnp2, respectively, were obtained by PCR. Inverse PCR was then conducted to clone the $5^{\prime}$ and $3^{\prime}$ flanking sequences of these fragments. For $m n p 1$, an amplified product of $1661 \mathrm{bp}$ was obtained from inverse PCR. After dividing the $1661 \mathrm{bp}$ into two parts at the $B g l \mathrm{II}$ restriction site and reintegrating with the $1014 \mathrm{bp}$ fragment, a $2379 \mathrm{bp}$ fragment was obtained that encompassed an intact $5^{\prime}$ and $3^{\prime}$ flanking sequence of mnp1. In parallel, RT-PCR and $5^{\prime} / 3^{\prime}$-RACE were performed to amplify the cDNA sequence of mnp1. Full-length cDNA sequences of the mnp1 gene consisted of 1331 nucleotides. Four short introns were found in $m n p 1$ sized between 60 and $80 \mathrm{bp}$. All intron splice junction regions belonged to the GT-AG rule [26]. The mnp1 gene showed $86 \%$ nucleotide sequence identity with mnp1 from Lenzites gibbosa CB-1 (FJ848739.2). The mnp1 corresponded to a protein of 364 amino acids. Sequence analysis of the deduced amino acids of MnP1 by SignalP 4.0 [25] revealed the presence of a putative signal peptide of 21 amino acids, with a cleavage site between Ser-21 and Ala-22 residues. The mature protein of MnP1 contained 343 amino acids.

For $m n p 2$, an amplified product of $1711 \mathrm{bp}$ was obtained from inverse PCR. After dividing the $1711 \mathrm{bp}$ into two parts at the StyI restriction site and reintegrating with the $1016 \mathrm{bp}$ fragment, a $2312 \mathrm{bp}$ fragment containing intact $5^{\prime}$ and $3^{\prime}$ flanking sequence of $m n p 2$ was obtained. In parallel, RT-PCR and $5^{\prime} / 3^{\prime}$-RACE were performed to amplify the cDNA sequence of mnp2. Full-length cDNA sequences of the mnp 2 gene consisted of 1306 nucleotides. The alignment of cDNA and intact sequence mnp2 revealed five introns. The nucleotide sequence of $m n p 2$ showed $84 \%$ identity with $m n p 2$ from L. gibbosa 
CB-1 (JQ388597.1). The mnp2 gene predicted 366 amino-acid-encoded protein, and a putative 21 amino acid signal peptide was identified with a putative cleavage site between Gln-21 and Ala-22 residues. The mature protein of MnP2 contained 345 amino acids.
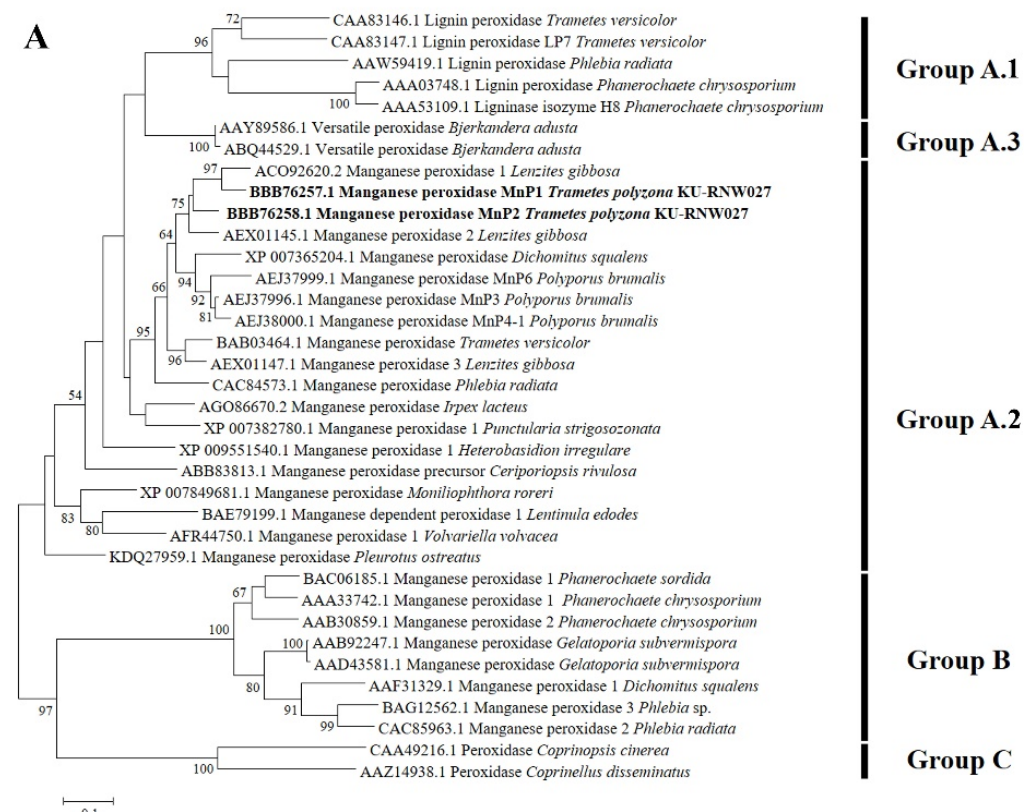

Group A.3

Group A.2

Group B

Group C

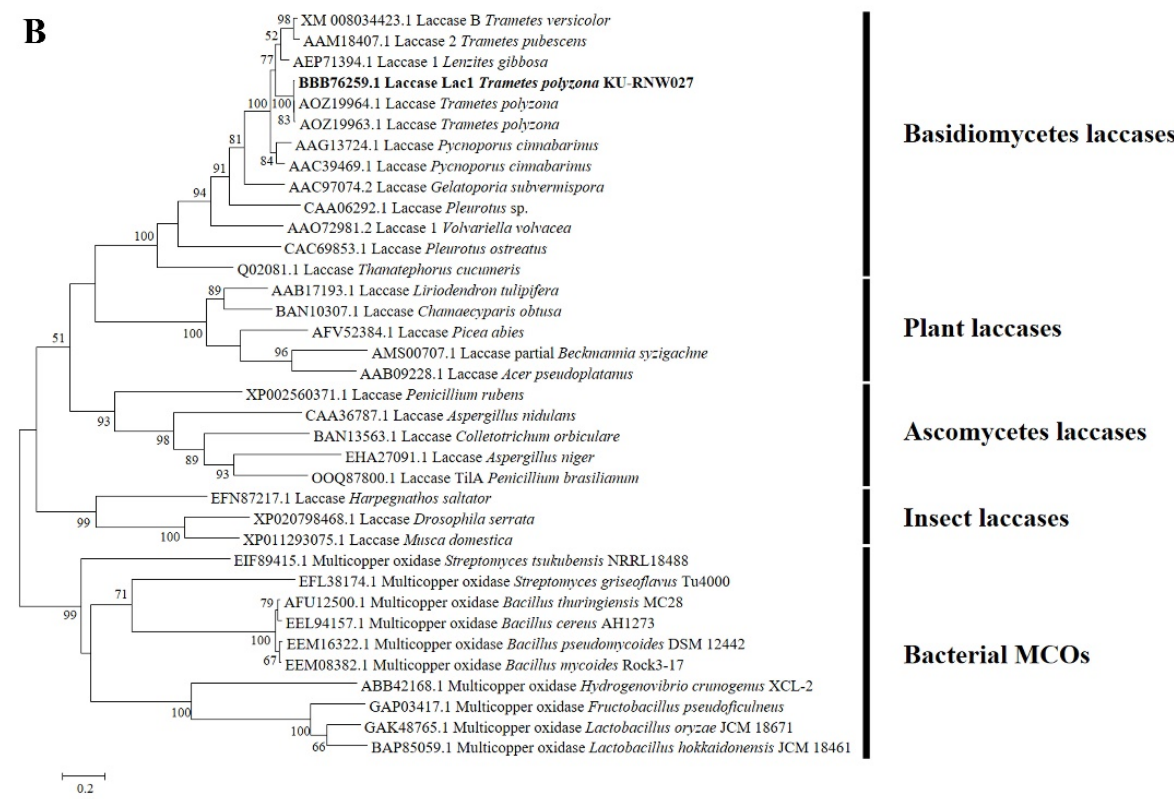

Figure 1. (A) Phylogenetic tree of class II fungal secreted heme peroxidases and (B) multiple copper oxidases. Maximum likelihood trees of 34 complete ORF translated amino acids for class II fungal secreted heme peroxidase and 35 complete ORF translated amino acids for multiple copper oxidases were constructed using Mega version 6.0. Confidence values above 50\% obtained from 1000 bootstrap replications are indicated at branch nodes. The scale bar indicates the number of amino acid substitutions per site.

A phylogenetic tree was constructed using the deduced amino acid sequences of MnP1 and MnP2 together with the other 34 complete amino acid sequences of class II fungal secretion heme peroxidases (Figure 1A). Phylogenetic analysis revealed that MnP1 and MnP2 of T. polyzona KU-RNW027 are clustered within subfamily A.2 clade. The two MnPs were short-type hybrid MnPs with no exhibited lignin peroxidase activity. They were distinctively distinguished from subclasses $B$ and $C$, which are 
typically long-MnP and other peroxidases, respectively [27]. MnP1 is close to MnP1 from L. gibbosa CB-1 (ACO92620.2) at 90\% identity. MnP2 has 86\% identity with MnP2 from L. gibbosa CB-1 (AEX01145.1). MnP1 and MnP2 of T. polyzona KU-RNW027 had only 88\% identities in their deduced amino acid sequences, suggesting that they are distinctive MnPs.

\begin{tabular}{|c|c|c|}
\hline & & \\
\hline $\mathrm{TP}-\mathrm{MnP} 1$ & MAFKTLASFVSLLAAFQVANSAVTRRVTCSNGQQTA-NAACCALFP ILDDIQQNLFDGGE & 59 \\
\hline $\mathrm{TP}-\mathrm{MnP} 2$ & MAFKTLASFVAVLAALQVANGALTRRVTCPDGVNTASNAACCALFPVLDDIQKNLFDGGQ & 60 \\
\hline LG-MnP1 & MAFKLLASFVSLLAAIQVANGAATRRVTCATGQTTT-NAACCALFPVIDDIQTNLFDGGE & 59 \\
\hline LG-MnP2 & MAFKILASS ISVLAALQAANGAVTRRVTCPDGVNIASNAACCALFPVLDDIQKNLFDGGE & 60 \\
\hline DS-MnP1 & MVFK--ALLISVLAAFQITKGALIRRATCSDGTVVA-NSACCVLIPVIQDIQENLFDGGE & 57 \\
\hline $\mathrm{PB}-\mathrm{MnP} 6$ & MAFAILASFVSALAALQVANGALTRRVTCADGSVTS-NAACCALFPVIQDLQANLFDNGG & 59 \\
\hline TV-MnP1 & MAFKTLASLLSVLVTIQVASGALTRRVACPDGVNTATNAACCQLFAVRDDIQQNLFDGGE & 60 \\
\hline & 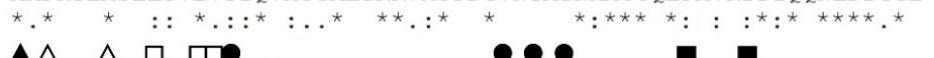 & \\
\hline TP-MnP1 & $\underset{\text { CGEEVHESLRLTFHDAIGISPKIAATGVFGGGGADGSIAIFEDIETNEHANNGVDEIIDE }}{\Delta} \Delta \underset{\square}{\Delta}$ & 19 \\
\hline $\mathrm{TP}-\mathrm{MnP} 2$ & CGEEVHESLRLTFHDAIGISPKIAATGVFGGGGADGSIALFEDIETNFHANNGVDEIIDE & \\
\hline $\mathrm{LG}-\mathrm{MnP} 1$ & CGEEVHESLRLTFHDAIGISPKMSATGVFGGGGADGSIAIFEDIETNFHANNGVDEIIDE & \\
\hline $\mathrm{LG}-\mathrm{MnP} 2$ & CGEKVHESLRLTFHDAIGISPEIAATGAFGGGGADGSIAIFDDIETNLYANNGVDEIIGE & \\
\hline $\mathrm{DS}-\mathrm{MnP} 1$ & CGEEVHESLRLTFHDAIGISPAIAATGVFGGGGADGSI ILFEDIEPNEHANNGVDE I IDE & \\
\hline $\mathrm{PB}-\mathrm{MnP} 6$ & CGEDVHESLRLTFHDAIGISPAIAARGQFGGGGADGSIALFEDIETNEHANLGVDEIIDE & \\
\hline TV-MnP1 & CGEEVHESLRLTFHDAIGISPSIASRGQFGGGGADGSIALFEDIETNFHANLGVDEI IDE & \\
\hline & 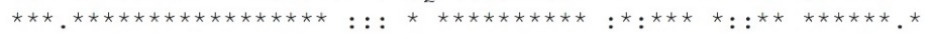 & \\
\hline & $\Delta$ & \\
\hline $\mathrm{TP}-\mathrm{MnP} 1$ & QKPFIARHNISTADFIQFAGAIGVSNCPGAPRLDVFIGRKDATQPAPDKTVPEPFDSVDS & \\
\hline $\mathrm{TP}-\mathrm{MnP} 2$ & QKPFIARHNITTADFIQFAGAIGVSNCPGAPRLDVFVGRKDATQPAPDKTVPEPFDSVDD & \\
\hline $\mathrm{LG}-\mathrm{MnP} 1$ & QRPFIQRHNLTTADFIQLAGA IGVSNCPGAPRLDVFIGRKDATQPAPDLTVPEPFDTVDS & \\
\hline $\mathrm{LG}-\mathrm{MnP} 2$ & QKPFIARHNLTTADFIQFAGAIGVSNCPGAPRLDVFVGRKDATQHAPDKTVPEPFDTVDS & \\
\hline $\mathrm{DS}-\mathrm{MnP} 1$ & QKPIIAKHNITTADFIQLAGA IGVSNCPGAPQLNVFIGRPDATQPAPDKTVPEPFDSVDS & \\
\hline $\mathrm{PB}-\mathrm{MnP} 6$ & QRPLLQRSNISAADFIQLAGAIGVANCPGAPRLAVFVGRQDATQPAPDLTVPEPFDTVDS & \\
\hline $\mathrm{TV}-\mathrm{MnP} 1$ & QRPFIARHNLTTADF IQFAGA IGVSNCPGAPQLDVFIGRPDATQPAPDLTVPEPFDTVDS & \\
\hline & 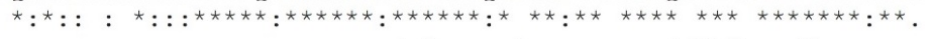 & \\
\hline & $\begin{array}{lllll}\boldsymbol{0} & \Delta & \boldsymbol{0} & \boldsymbol{0} & \boldsymbol{0}\end{array}$ & \\
\hline TP-MnP1 & ILARFA----DAGRFSPAEVVALLASHT-VAAADHVDPS I PGTPFDSTPELFDTQFFIET & \\
\hline $\mathrm{TP}-\mathrm{MnP} 2$ & ILARFE----DAGGFTAAEVVALLASGTRVAAADHVDPTI PGTPFDSTPERFDTQFFIET & \\
\hline LG-MnP1 & ILARFS----DAGRFSAAEVVALLASHT-IAAADHVDPT I PGTPFDSTPELFDTQFFIET & \\
\hline $\mathrm{LG}-\mathrm{MnP} 2$ & ILARFA----DAGGFSPEEVVALLASHT-IAAADHVDPSI PGTPFDSTPELFDTQFFIET & \\
\hline $\mathrm{DS}-\mathrm{MnP} 1$ & ILARFQDAFSDVGGFTPAEVVALLASHT-IAAADHVDPS I PGTPFDSTPELFDTQFFIET & \\
\hline $\mathrm{PB}-\mathrm{MnP} 6$ & ILQRFE----DAGGFTPAEVVALLASHT-IAAADHVDPS I PGTPFDSTPELFDTQFFIET & 4 \\
\hline $\mathrm{TV}-\mathrm{MnP} 1$ & IIERFS----DAGGETPAEIVALLVSHT-IAAADHVDPSI PGTPFDSTPEEFDTQEFIET & \\
\hline & 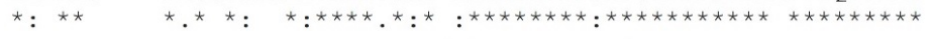 & \\
\hline & & \\
\hline $\mathrm{TP}-\mathrm{MnP} 1$ & QLKGTLFPGTAGNQGEVESPVRGELRLQSDEEI & \\
\hline $\mathrm{TP}-\mathrm{MnP} 2$ & QLRGTLFPGTGGNQGEVESPLQGELRLQSDAELARDSRTACEWQSFVNNQAKMQSAFKAA & \\
\hline $\mathrm{LG}-\mathrm{MnP} 1$ & QLKGTLFPGTAGNQGEVTSPLHGEIRLQSDFELARDQRTACEWQSFVNNQAKLQSAFKAA & \\
\hline $\mathrm{LG}-\mathrm{MnP} 2$ & QLRGTLFPGTGGNQGEVESPLHGEIRLQSDSELARDSHTACEWQSFVNNQAKLQSAFKAA & \\
\hline $\mathrm{DS}-\mathrm{MnP} 1$ & QLRGTLFPGTGGNQGEAQSALAGELRLQSDSELARDSRTACEWQSFVNNQAKLQSAFKAA & \\
\hline $\mathrm{PB}-\mathrm{MnP} 6$ & QLRGTLFPGTPGNQGEVESPVPGEIRLQSDSELARDSRTACEWQSFVNNQAKLQSAFAAA & \\
\hline $\mathrm{TV}-\mathrm{MnP} 1$ & QLRGTLFPGTGGNQGEVESPLRGELRLQSDSELARDSRTACEWQSFVNNQAKLQSAFKAA & \\
\hline & 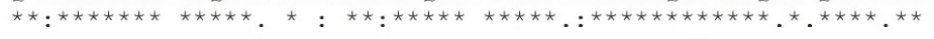 & \\
\hline & $\Delta$ & \\
\hline $\mathrm{TP}-\mathrm{MnP} 1$ & ERKMTVLGHNVRDLIDCSDVVPNPPAPASQAHFPAGLSHRDVEQACRQTPFPVLPTDPGP & \\
\hline $\mathrm{TP}-\mathrm{MnP} 2$ & FRKMTVLGHNVNDLVDCSEVVPTPPAPASNAHFPAGLSNKDVEQACSSTPFPTLPTDPGP & \\
\hline LG-MnP1 & FRKMTVLGSNVHDLVDCSDVVPTPPAPASKAHFPAGQFHRDVEQACRNTPFPVLPTDPGP & \\
\hline $\mathrm{LG}-\mathrm{MnP} 2$ & FRKMTVLGSDIGDLVDCSEVVPTPPAPASTAHFPAGLS IADIEQACASTPFPTLPTDPGP & \\
\hline $\mathrm{DS}-\mathrm{MnP} 1$ & FRRMS ILGHDESSLIDCSDVVPVPPAPASDAHFPAGQT IDDVEQACASTPFPTLPTDPGP & \\
\hline $\mathrm{PB}-\mathrm{MnP} 6$ & FRKMT ILGHDESELVDCSDVVQQPP PPASAAHFPAGLSNADIEQACASTPFPTL PTDPGP & \\
\hline TV-MnP1 & ERKMTVLGHDESLLIECSELVPTPPPATSVAHFPAGLSNADVEQACADTPFPTLPTDPGP & \\
\hline & 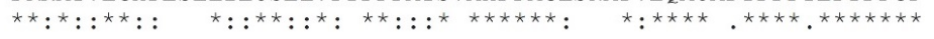 & \\
\hline TP-MnP1 & ATSVAPVPPS & \\
\hline $\mathrm{TP}-\mathrm{MnP} 2$ & VTSVAPVPPS & \\
\hline $\mathrm{LG}-\mathrm{MnP} 1$ & VTSVAPVPPS & \\
\hline LG-MnP2 & VTSVAPVPPS & \\
\hline $\mathrm{DS}-\mathrm{MnP} 1$ & ASSVAPVPPS & \\
\hline $\mathrm{PB}-\mathrm{MnP} 6$ & VTSVAPVPPS & \\
\hline TV-MnP1 & VTTVAPVPPS & \\
\hline &.$:: * * * * * * *$ & \\
\hline
\end{tabular}

Figure 2. Deduced amino acid sequences of two new mnp genes. The shaded amino acid sequence is the predicted signal peptide. Eight conserved cysteine residues are indicated by triangles $(\boldsymbol{\Delta})$. Conserved heme pocket residues are indicated by solid rectangles $(\boldsymbol{\square}) . \mathrm{Mn}^{2+}$ binding sites are indicated by hollow triangles $(\Delta) . \mathrm{Ca}^{2+}$ binding sites are indicated by circles $(\mathbf{)})$. Oxidation sites of the substrate are indicated by hollow rectangles (ם). TP: Trametes polyzona; LG: Lenzites gibbosa; DS: Dichomitus squalens; PB: Polyporus brumalis; TV: Trametes versicolor. A putative signal peptide was analyzed using SignalP 4.0 [25]. 
Important catalytic and conserved amino acid residues are also included in the deduced amino acid sequences of the two new MnPs and another white rot fungi MnP (Figure 2). Eight conserved cysteine residues were identified in $\mathrm{MnP1}$ and $\mathrm{MnP} 2$. At a functional level, amino acid residues are closely related to peroxidase oxidation sites and heme pocket residues, and $\mathrm{Mn}^{2+}$ and $\mathrm{Ca}^{2+}$ binding sites [28] are conserved in the two new deduced MnP sequences.

A 1625 bp fragment of lac1 was obtained by PCR using Lacf and Lacr as degenerate primers. To clone the $5^{\prime}$ and $3^{\prime}$ flanking of Lac1 sequence, inverse PCR was performed, yielding a $1623 \mathrm{bp}$ segment. After dividing the $1523 \mathrm{bp}$ into two parts at the BamHI restriction site and reintegrating with the 1625 bp fragment, a 3016 bp fragment of lac1 was obtained. RT-PCR and 5'/3'-RACE were performed in parallel to amplify the cDNA sequence of lac1. Full-length cDNA sequences of the lac1 gene consisted of 1809 nucleotides. The alignment of cDNA and intact sequence lac1 revealed 10 introns. The nucleotide sequence of lac1 has 97\% identity with lac from T. polyzona MUCL:38443 (KT802746.1). The lac1 corresponded to a protein of 520 amino acids. The deduced amino acid sequence of Lac1 showed 99\% identity with laccase from T. polyzona MUCL:38443 (AOZ19964.1). SignalP 4.0 analysis revealed that pre-mature protein of Lac1 of T. polyzona KU-RNW027 consisted of a putative 21 amino acid signal peptide with a cleavage site between Ala-21 and Ala-22 residues. The mature Lac1 protein had 499 amino acids.

Phylogenetic analysis of the deduced amino acid sequence of Lac1 was constructed with the other 35 complete amino acid sequences of multiple copper oxidases from different sources, including Basidiomycetes, Ascomycetes, plants, insects, and bacteria. The results revealed that Lac1 is clustered in the Basidiomycetes laccase clade in the same branch as laccases from the other T. polyzona strains (Figure 1B).

The ligninolytic system of T. polyzona KU-RNW027 consisted of two MnP-encoding genes and one laccase-encoding gene. According to their deduced amino acid sequences, MnP1 and MnP2 are new manganese peroxidases in class II fungal secretion heme peroxidase, whereas Lac1 is similar to other $T$. polyzona laccases. The intact nucleotide sequences of mnp1, mnp2, and lac1 were deposited in GenBank under accession numbers LC340363, LC464698, and LC464699, respectively, whereas full-length cDNA sequences of mnp1, mnp2, and lac1 are LC340360, LC340361, and LC340362, respectively.

\subsection{Promoter of Ligninolytic Enzyme-Encoding Genes}

The $5^{\prime}$-flanking sequences upstream of the start codon ATG of the mnp1, mnp2, and lac1 genes were obtained by inverse PCR. The putative cis-acting regulatory sequence elements, which are involved in their transcriptional regulations, were analyzed. The putative promoter region of mnp1 $730 \mathrm{bp}$ upstream of the start codon is presented in Figure 3A. We found one TATA box (TATAA) 79 from the start codon (ATG) in the mnp1 promoter. No CAAT box was found in the promoter of mnp1, whereas two inverted CAAT motifs (ATTGG) were observed at positions -205 and -301 . We found one potential light responsive element (LRE) composed of the 6 bp CCRCCC motif [20] at -307. We found two xenobiotic response element (XRE) motifs, TNGCGTG and CACGCW [29], at -120 and -607, respectively. Metal responsive element (MRE) motif, TGCRCNC [18] at -147 and -452 ; two copper responsive element (CRE) motifs HWHNNGCTGD [30] at -323 and -337; one iron responsive element (IRE) motif CAGTGH [31] at -533; three putative CreA-binding site (cAMP-mediated glucose repression element) SYGGRG [32] at -90, -343, and -434; and nine heat shock elements (HSEs) NGAAN [33] at $-64,-230,-339,-470,-624,-669,-688,-697$, and -708 were identified on the promoter region of mnp1.

Figure 3B depicts $894 \mathrm{bp}$ of the putative promoter region of mnp2. One TATA box at -93 relative to start codon ATG was found in the promoter of mnp2. Similar to the promoter of $m n p 1$, two inverted CAAT motifs were found at positions -170 and -275 , and no direct CAAT box was present in the mnp2 promoter. Remarkably, we found two LREs at -282 and -569 relative to the start codon ATG of mnp2. Two MREs at -139 and -408 , one XRE at -195 , one CRE at -298 , two CreA binding sites at -78 and -652 , and 10 HSEs at $-54,-104,-187,-243,-318,-377,-456,-517,-558$, and -808 were identified on the mnp2 promoter region. 


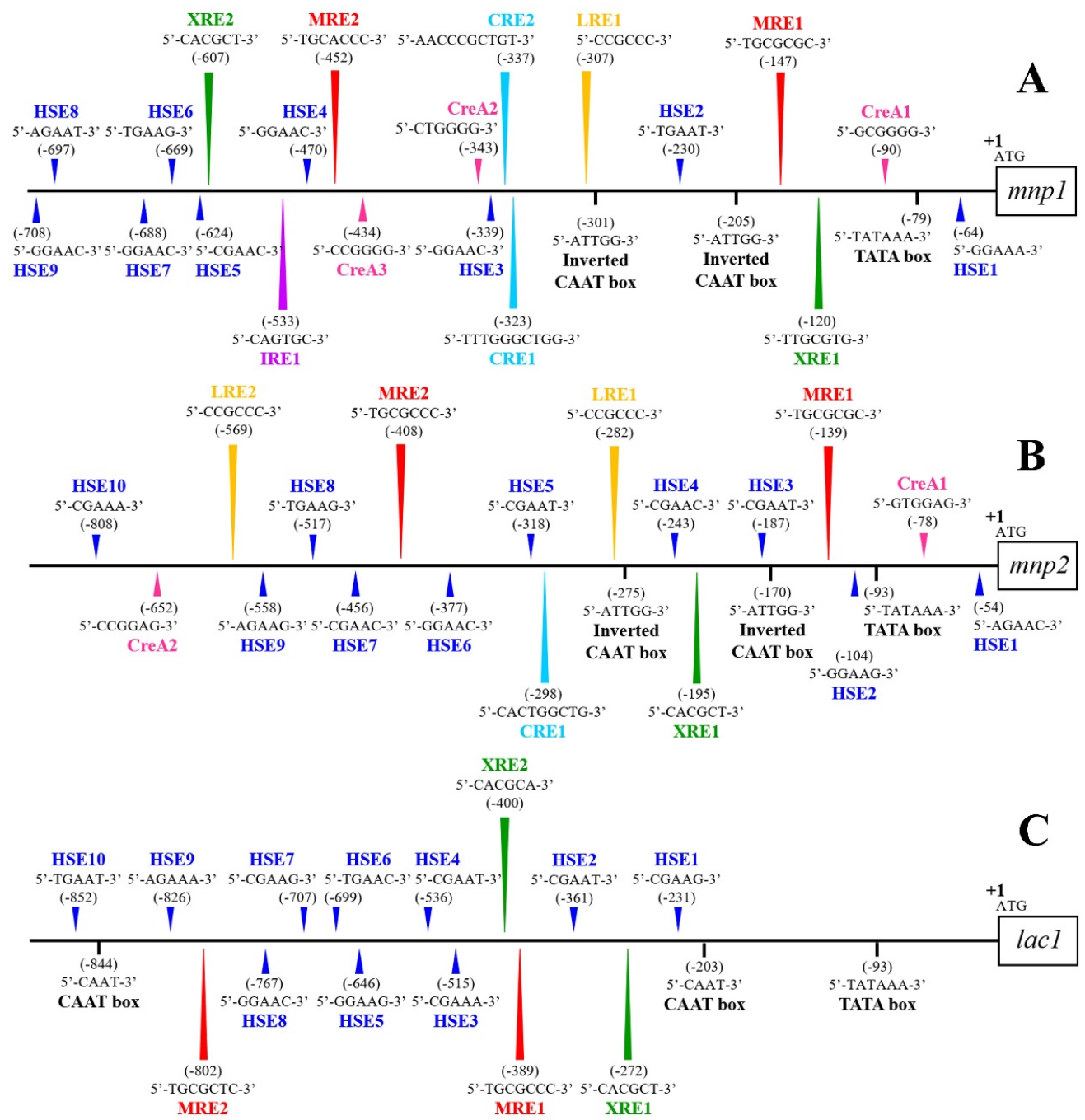

Figure 3. The scheme of the cis-acting element of (A) mnp1, (B) mnp2, and (C) lac1 upstream promoter from ATG. LRE, light responsive element; MRE, metal ion responsive element; XRE, xenobiotic responsive element; CRE, copper responsive element; IRE, iron responsive element; CreA, CreA binding site or cAMP responsive element; and HSE, heat shock element. The first nucleotide of start codon (ATG) is labeled as +1 .

We depict $906 \mathrm{bp}$ of the putative promoter region of lac1 in Figure 3C. One TATA box and two CAAT boxes were identified at $-93,-203$, and -844 , respectively. Unlike the mnp 1 and $m n p 2$ promoters, only three kinds of cis-acting regulatory sequence elements were observed on the lac1 promoter as MRE, XRE, and HSE motifs. Two MRE motifs were found at -389 and -802; two XRE motifs were found at -272 and -400 . Ten HSE motifs were found at $-231,-361,-515,-536,-646,-699,-707,-767$, -826 , and -852. LRE, CRE, IRE, and CreA binding sites were not identified in the lac1 promoter.

The promoter regions of $m n p 1$, mnp2, and lac1 showed low sequence similarity with those of the other fungi. We found unique sequences in the respective genes. However, all promoters shared common regulatory elements, such as MRE, XRE, and HSE [19,28,30,31]. Conserved sequences, TATA boxes, and CAAT boxes were commonly found in the core promoter region as essential for gene expression. The TATA box is known as a transcription initiator site [34], whereas the CAAT box is an RNA polymerase recognition site [35]. The promoter regions of ligninolytic enzyme-encoding genes usually contain one TATA box and at least one CAAT box at positions between - 30 and -1145 from the start codon to initiate the transcription [18]. In contrast, no direct CAAT box was found in the promoter regions of mnp 1 and mnp2. Two inverted CAAT boxes were identified in both promoters, in accordance with results reported by Chen et al. [28]. 
In previous reports, no LRE was identified on the promoters of ligninolytic enzyme-encoding genes. Interestingly, we found one and two LREs in the promoters of T. polyzona KU-RNW027 mnp1 and $m n p 2$, respectively. These may drive regulation by light.

\subsection{Regulation of Ligninolytic Enzyme Production and Gene Expression by Different Wavelengths of Light}

\subsubsection{Preliminary Plate Assay Study}

Under continuous lighting, the size of the orange zone that indicates ligninolytic enzyme activities was larger than in the dark control (Figure 4). This implied that light enhances the ligninolytic enzyme production of T. polyzona KU-RNW027. Therefore, we determined the ligninolytic enzyme activities and their gene expressions under different wavelengths of light. However, light did not affect fungal growth, since the diameters of fungal colonies on agar plates were no different under light and dark conditions.

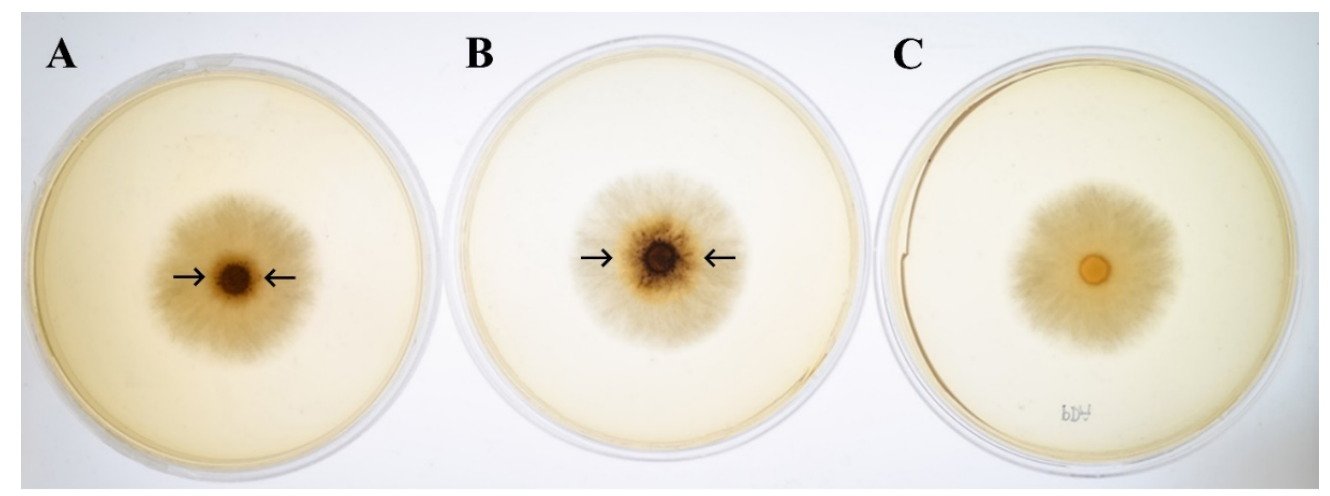

Figure 4. Ligninolytic enzyme activity of T. polyzona KU-RNW027 on agar plates. The fungus was grown on PDA supplemented with $1 \mathrm{mM}$ 2,6-DMP under (A) dark and (B) continuous lighting conditions. The fungus grown on PDA without 2,6-DMP under light was used as a control (C). Ligninolytic enzymes oxidized 2,6-DMP to produce the orange product of the benzoquinone compound. Arrows indicate visualization of the enzyme activity.

\subsubsection{Effect of Light on Transcription Levels and Enzyme Production}

Light of tungsten (320-1100 nm) significantly stimulated MnP activity but not laccase activity. $\mathrm{MnP}$ activities were observed as being 1.5 times higher under light compared with the dark control (Figure 5A). In the dark, T. polyzona KU-RNW027 produced both MnP and laccase at 2.2 and $1.9 \mathrm{U} / \mathrm{mL}$, respectively. Reduction of both enzyme activities was caused by blue light. Only 0.81 and $0.59 \mathrm{U} / \mathrm{mL}$ of $\mathrm{MnP}$ and laccase activities were detected under blue light, respectively. However, tungsten light and blue light did not affect fungal growth. The biomass of the fungus averaged $1.2 \pm 0.07 \mathrm{~g} / \mathrm{L}$ in all the conditions tested.

The highest levels of $m n p 1$ and $m n p 2$ transcripts were observed under tungsten light irradiation at 6.5 and 3.8-fold induction of mnp1 and mnp2, respectively, compared to dark condition (Figure 5B). This result showed the correlation of the induction of both mnp gene transcriptions by tungsten light illumination with increasing $\mathrm{MnP}$ activity. However, tungsten light only up-regulated the mnp genes but not the lac gene. Under blue light illumination, levels of mnp1, mnp2, and lac1 transcripts were not significantly different from those observed under the dark control. Blue light had no effect on either mnp or lac gene expressions. However, blue light affected both enzyme activities (Figure 5A,B).

Tungsten light up-regulated MnP activity and its gene expression compared with the dark condition. Laccase activity and its gene transcription levels were not affected by light, in good agreement with the observation that no LRE was identified on the lac1 promoter region. Previous studies reported the effect of light on $\mathrm{MnP}$, laccase, and lignin peroxidase production in submerged cultures of $C$. unicolor, P. sanguineus, P. lindtneri, and P. chrysosporium [14,15]. Light also stimulated the production of MnP 
from solid-state ash sawdust C. unicolor culture [36]. However, analysis of ligninolytic enzymes gene expression in C. unicolor revealed that wood degradation properties may not only be dependent on lighting conditions but also result from overall stimulation of fungal metabolism by daylight [37].
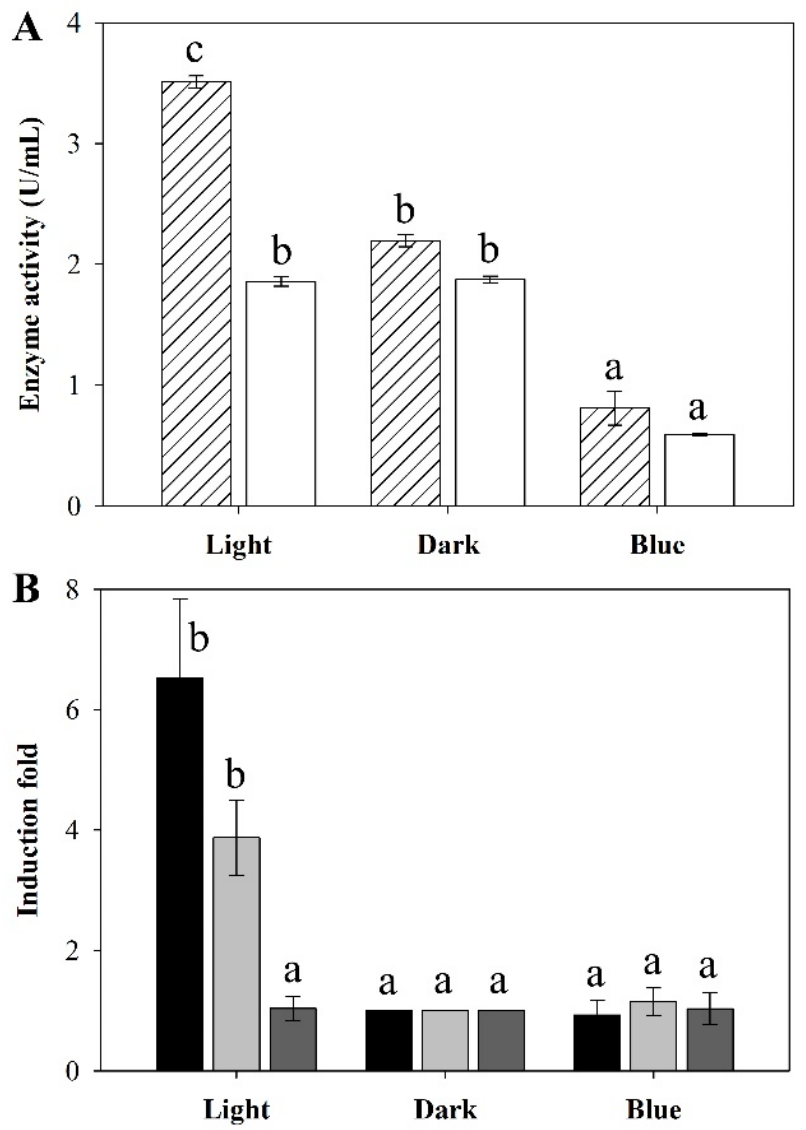

Figure 5. Effect of different wavelengths of light on (A) ligninolytic enzyme productions and (B) gene expressions in T. polyzona KU-RNW027. $\mathrm{MnP}(\square \square$ ) and laccase ( $\square$ ) activities in the culture supernatant were determined after 7 days of cultivation under different wavelengths of light.

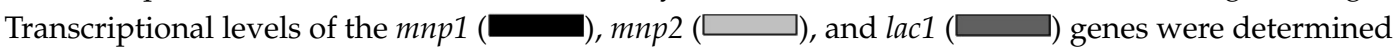
using mycelia harvested from the cultures after 7 days of cultivation under different wavelengths of light. Transcription levels of mnp1, mnp2, and lac1 are shown as induction fold values relative to those observed under the dark condition. Error bars represent standard deviation $(n=3)$. a, b, and c represent significant enzyme production and gene expression compared to the control $(p<0.05)$.

\subsubsection{Effect of Light on Ligninolytic Enzyme Stability}

Compared to the equivalent dark controls, both $\mathrm{MnP}$ and laccase activities were relatively stable under tungsten light for the first six hours of exposure, retaining 90\%-95\% initial activity respectively. Thereafter, both enzymes were progressively effected to a greater extent, but still retained $60 \%-75 \%$ initial activity even after $72 \mathrm{~h}$ of exposure. Conversely, over the same time course, blue light had a much stronger negative effect, with the retained activity of both enzymes falling to $70 \%$ after only $6 \mathrm{~h}$ of exposure. For $\mathrm{MnP}$, retained activity progressive declined to $39 \%$ after $72 \mathrm{~h}$ of exposure, whereas for laccase the detrimental effect became much more noticeable with increased exposure such that the retained activity of this enzyme had declined to $6 \%$ of its initial level at $72 \mathrm{~h}$. (Figure 6)

The biochemical basis of the detrimental effects of exposure to blue light on both the tested MnP and laccase from KU-RNW027 remains currently uncharacterized. However, blue light has been previously shown to effect the biological functions of many proteins [1]; specifically, blue light can change the activity of the endonuclease PvuII by changing the sulfur-sulfur bond configuration of the enzyme in a way that reduces enzyme-substrate interaction [38]. Multiple cysteine residues, and 
therefore, potentially disulfide bonds, exist in both the tested MnP and laccase enzymes (Figure 2), and so disruption of these particular sulfur-sulfur bonds could be a possible explanation for the observed effects of blue light on these enzymes. Confirmation of the actual mode of action of blue light on KU-RNW027 requires much more extensive investigation.
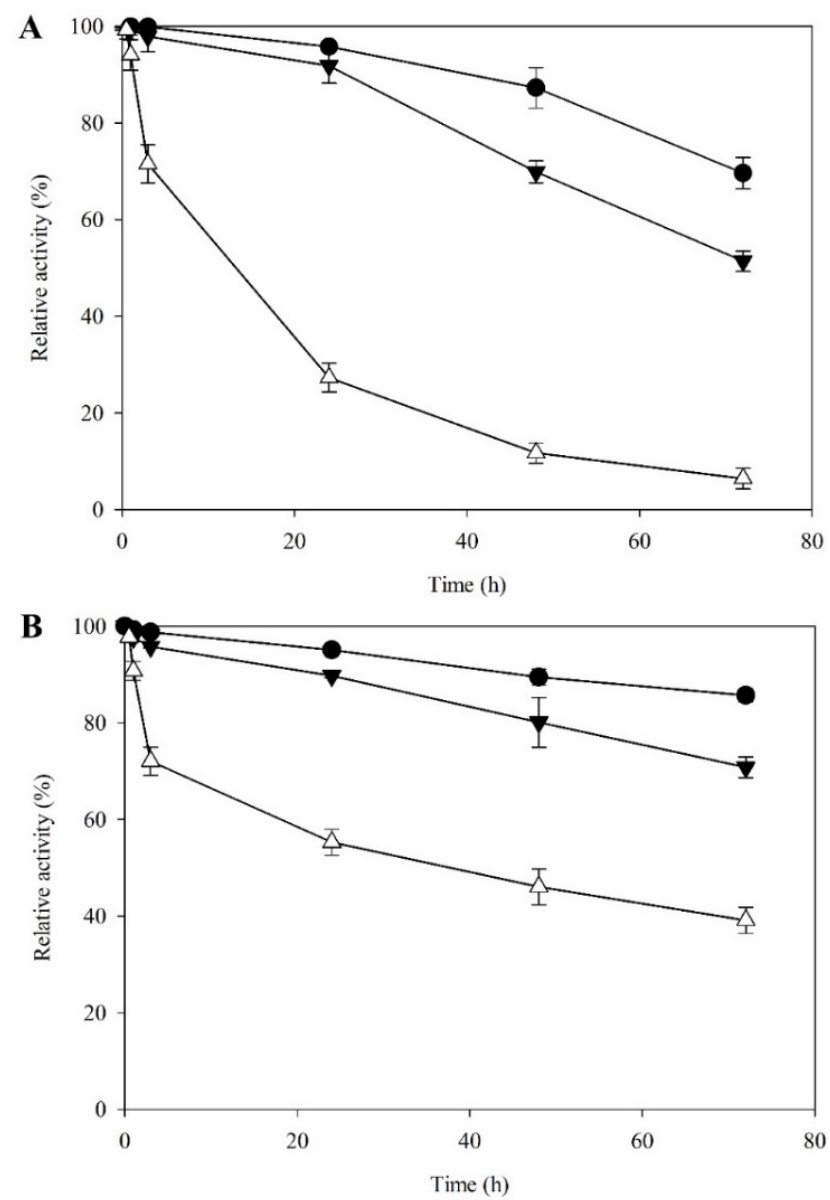

Figure 6. Time course of (A) laccase and (B) MnP stability under different wavelengths of light. Error bars represent standard deviation $(n=3)$. Dark condition $(-\boldsymbol{C})$, tungsten light $(\boldsymbol{\nabla})$, and blue light $(\triangle \smile)$.

\section{Conclusions}

Our findings suggested two new manganese peroxidases and one laccase in the ligninolytic system of T. polyzona KU-RNW027. Ligninolytic enzyme production and gene expression in T. polyzona KU-RNW027 can be regulated by light. This is the first report on LREs identified in the mnp promoter region in fungi. Tungsten light enhanced MnP production but not for laccase, whereas blue light impacted enzyme stability. Our findings effectively supported improvement of ligninolytic enzyme production in the white rot fungus T. polyzona KU-RNW027. This result benefits the application of an eco-friendly approach, especially in toxic aromatic compound bioremediation.

Supplementary Materials: The supplementary materials are available online at http://www.mdpi.com/2076-2607/ 8/6/852/s1.

Author Contributions: Conceptualization, T.K., K.S. and L.C.; methodology, P.L., E.K., T.K. and L.C.; software, P.L. and E.K.; validation, P.L., E.K. and M.S.; formal analysis, P.L., E.K., M.S. and C.T.; investigation, T.K., K.S. and L.C.; resources, K.S. and L.C.; data curation, P.L. and E.K.; writing-original draft preparation, P.L.; writing-review and editing, P.L., E.K., M.S., T.K., K.S., C.T. and L.C.; visualization, T.K., K.S. and L.C.; supervision, T.K., K.S. and L.C.; project administration, K.S. and L.C.; funding acquisition, K.S. and L.C. All authors have read and agreed to the published version of the manuscript. 
Funding: We thank the Kasetsart University Research and Development Institute (KURDI), Kasetsart University for research grant support. Thanks are also given to The Thailand Research Fund through The Royal Golden Jubilee Ph.D. Program (grant number PHD/0214/2553) for assistance rendered to Mr. Piyangkun Lueangjaroenkit.

Conflicts of Interest: The authors declare no conflict of interest.

\section{References}

1. Purschwitz, J.; Muller, S.; Kastner, C.; Fischer, R. Seeing the rainbow: Light sensing in fungi. Curr. Opin. Microbiol. 2006, 9, 566-571. [CrossRef] [PubMed]

2. Avalos, J.; Estrada, A.F. Regulation by light in Fusarium. Fungal Genet. Biol. 2018, 47, 930-938. [CrossRef] [PubMed]

3. Schwerdtfeger, C.; Linden, H. VIVID is a favoprotein and serves as a fungal blue light photoreceptor for photoadaptation. EMBO J. 2003, 22, 4846-4855. [CrossRef] [PubMed]

4. Idnurm, A.; Verma, S.; Corrochano, L.M. A glimpse into the basis of vision in the kingdom Mycota. Fungal Genet. Biol. 2010, 47, 881-892. [CrossRef]

5. Verma, S.; Idnurm, A. The Uve1 endonuclease is regulated by the white collar complex to protect Cryptococcus neoformans from UV damage. PLoS Genet. 2013, 9, e1003769. [CrossRef] [PubMed]

6. Miyake, T.; Mori, A.; Kii, T.; Okuno, T.; Usui, Y.; Sato, F.; Sammoto, H.; Watanabe, A.; Kariyama, M. Light effects on cell development and secondary metabolism in Monascus. J. Ind. Microbiol. Biotechnol. 2005, 32, 103-108. [CrossRef]

7. Chen, D.; Gibson, E.S.; Kennedy, M.J. A light-triggered protein secretion system. J. Cell Biol. 2013, 201, 631-640. [CrossRef]

8. Schumacher, J. How light affects the life of Botrytis. Fungal Genet. Biol. 2017, 106, 26-41. [CrossRef]

9. Buck, J.W.; Dong, W.; Mueller, D.S. Effect of light exposure on in vitro germination and germ tube growth of eight species of rust fungi. Mycologia 2010, 102, 1134-1140. [CrossRef]

10. Kamada, T.; Sano, H.; Nakazawa, T.; Nakahori, K. Regulation of fruiting body photomorphogenesis in Coprinopsis cinerea. Fungal Genet. Biol. 2010, 47, 917-921. [CrossRef]

11. Yu, S.M.; Ramkumar, G.; Lee, Y.H. Light quality influences the virulence and physiological responses of Colletotrichum acutatum causing anthracnose in pepper plants. J. Appl. Microbiol. 2013, 115, 509-516. [CrossRef]

12. Castrillo, M.; Luque, E.M.; Pardo-Medina, J.; Limon, M.C.; Corrochano, L.M.; Avalos, J. Transcriptional basis of enhanced photoinduction of carotenoid biosynthesis at low temperature in the fungus Neurospora crassa. Res. Microbiol. 2018, 169, 78-89. [CrossRef] [PubMed]

13. Velmurugan, P.; Lee, Y.H.; Venil, C.K.; Lakshmanaperumalsamy, P.; Chae, J.; Oh, B. Effect of light on growth, intracellular and extracellular pigment production by five pigment-producing filamentous fungi in synthetic medium. J. Biosci. Bioeng. 2010, 109, 346-350. [CrossRef] [PubMed]

14. Ramírez, D.A.; Muñoz, S.V.; Atehortua, L.; Michel, F.C., Jr. Effects of different wavelengths of light on lignin peroxidase production by the white-rot fungi Phanerochaete chrysosporium grown in submerged cultures. Bioresour. Technol. 2010, 101, 9213-9220. [CrossRef] [PubMed]

15. Janusz, G.; Sulej, J.; Jaszek, M.; Osińska-Jaroszuk, M. Effect of different wavelengths of light on laccase, cellobiose dehydrogenase, and proteases produced by Cerrena unicolor, Pycnoporus sanguineus and Phlebia lindtneri. Acta. Biochem. Pol. 2016, 63, 223-228. [CrossRef]

16. Zhang, G.; Liu, P.; Wei, W.; Wang, X.; Wei, D.; Wang, W. A light-switchable bidirectional expression system in filamentous fungus Trichoderma reesei. J. Biotechnol. 2016, 240, 85-93. [CrossRef]

17. Piscitelli, A.; Giardina, P.; Lettera, V.; Pezzella, C.; Sannia, G.; Faraco, V. Induction and transcriptional regulation of laccases in fungi. Curr. Genom. 2011, 12, 104-112. [CrossRef]

18. Janusz, G.; Kucharzyk, K.H.; Pawlik, A.; Staszczak, M.; Paszczynski, A.J. Fungal laccase, manganese peroxidase and lignin peroxidase: Gene expression and regulation. Enzyme Microb. Technol. 2013, 52, 1-12. [CrossRef]

19. Yang, J.; Wang, G.; Ng, T.B.; Lin, J.; Ye, X. Laccase production and differential transcription of laccase genes in Cerrena sp. in response to metal ions, aromatic compounds and nutrients. Front. Microbiol. 2016, 6, 1558. [CrossRef]

20. Srivastav, A.; Mehta, S.; Lindlof, A.; Bhargava, S. Over-represented promoter motifs in abiotic stress-induced DREB genes of rice and sorghum and their probable role in regulation of gene expression. Plant Signal Behav. 2010, 5, 775-784. [CrossRef] 
21. Lueangjaroenkit, P.; Teerapatsakul, C.; Chitradon, L. Morphological characteristic regulation of ligninolytic enzyme produced by Trametes polyzona. Mycobiology 2018, 46, 396-406. [CrossRef] [PubMed]

22. Lueangjaroenkit, P.; Teerapatsakul, C.; Sakka, K.; Sakka, M.; Kimura, T.; Kunitake, E.; Chitradon, L. Two manganese peroxidases and a laccase of Trametes polyzona KU-RNW027 with novel properties for dye and pharmaceutical product degradation in redox mediator-free system. Mycobiology 2019, 47, 217-229. [CrossRef] [PubMed]

23. Kondo, R.; Harazono, K.; Sakai, K. Bleaching of hardwood kraft pulp with manganese peroxidase secreted from Phanerochaete sordida YK 624. Appl. Environ. Microbiol. 1994, 60, 4359-4363. [CrossRef]

24. Tamura, K.; Peterson, D.; Peterson, N.; Stecher, G.; Nei, M.; Kumar, S. MEGA5: Molecular evolutionary genetics analysis using maximum likelihood, evolutionary distance, and maximum parsimony. Mol. Biol. Evol. 2011, 28, 2731-2739. [CrossRef] [PubMed]

25. Petersen, T.N.; Brunak, S.; von Heijne, G.; Nielsen, H. SignalP 4.0: Discriminating signal peptides from transmembrane regions. Nat. Methods 2011, 8, 785-786. [CrossRef]

26. Shapiro, M.B.; Senapathy, P. RNA splice junctions of different classes of eukaryotes: Sequence statistics and functional implication in gene expression. Nucleic Acids Res. 1987, 11, 7155-7174. [CrossRef]

27. Hofrichter, M.; Ullrich, R.; Pecyna, M.J.; Liers, C.; Lundell, T. New and classic families of secreted fungal heme peroxidases. Appl. Microbiol. Biotechnol. 2010, 87, 871-897. [CrossRef]

28. Chen, W.; Zheng, L.; Jia, R.; Wang, N. Cloning and expression of a new manganese peroxidase from Irpex lacteus F17 and its application in decolorization of reactive black 5. Process Biochem. 2015, 50, 1748-1759. [CrossRef]

29. Reinhart, J.; Pearson, W.R. The structure of two murine class-Mu glutathione transferase genes coordinately induced by butylated hydroxyanisole. Arch. Biochem. Biophys. 1993, 303, 383-393. [CrossRef]

30. Nakade, K.; Nakagawa, Y.; Yano, A.; Konno, N.; Sato, T.; Sakamoto, Y. Effective induction of pblac1 laccase by copper ion in Polyporus brumalis ibrc05015. Fungal Biol. 2013, 117, 52-61. [CrossRef]

31. Yang, Y.; Wei, F.; Zhuo, R.; Fan, F.; Liu, H.; Zhang, C.; Ma, L.; Jiang, M.; Zhang, X. Enhancing the laccase production and laccase gene expression in the white-rot fungus Trametes velutina 5930 with great potential for biotechnological applications by different Metal ions and aromatic compounds. PLoS ONE 2013, 8, e79307. [CrossRef]

32. Takashima, S.; Iikura, H.; Nakamura, A.; Masaki, H.; Uozumi, T. Analysis of Crel binding sites in the Trichoderma reesei cbhl upstream region. FEMS Microbiol. Lett. 1996, 145, 361-366. [CrossRef]

33. Bonner, J.J.; Ballou, C.; Fackenthal, D.L. Interactions between DNA-Bound Trimers of the Yeast Heat Shock Factor. Mol. Cell Biol. 1994, 14, 501-508. [CrossRef]

34. Bae, S.; Han, H.W.; Moon, J. Functional analysis of the molecular interactions of TATA box-containing genes and essential genes. PLoS ONE 2015, 10, e0120848. [CrossRef]

35. Dai, Z.; An, K.; Edward, G.E.; An, G. Functional role of CAAT box element of the nopaline synthase (nos) promoter. J. Plant Biol. 1999, 42, 181-185. [CrossRef]

36. Pawlik, A.; Jaszek, M.; Sulej, J.; Janusz, G. Light-regulation synthesis of extra- and intracellular enzymes related to wood degradation by the white rot fungus Cerrena unicolor during solid-state fermentation on ash sawdust-based medium. Acta Biochim. Pol. 2019, 66, 419-425.

37. Pawlik, A.; Mazur, A.; Wielbo, J.; Koper, P.; Zebracki, K.; Kubik-Komar, A.; Janusz, G. RNA sequencing reveals differential gene expression of Cerrena unicolor in response to variable lighting conditions. Int. J. Mol. Sci. 2019, 20, 290. [CrossRef]

38. Schierling, B.; Noël, A.; Wende, W.; Hien, L.T.; Volkov, E.; Kubareva, E.; Oretskaya, T.; Kokkinidis, M.; Römpp, A.; Spengler, B.; et al. Controlling the enzymatic activity of a restriction enzyme by light. Proc. Natl. Acad. Sci. USA 2010, 107, 1361-1366. [CrossRef]

(C) 2020 by the authors. Licensee MDPI, Basel, Switzerland. This article is an open access article distributed under the terms and conditions of the Creative Commons Attribution (CC BY) license (http://creativecommons.org/licenses/by/4.0/). 